\title{
ETHNIC CHINESE ENTERPRISES AND THE EMBEDDEDNESS OF FAILURE
}

\section{Introduction}

Chinese businesspeople of both mainland and diasporic background operating in the global economy have been constructed as a transnational community sharing tacit knowledge of operations, strategies, competitors and markets, based on mutual trust and a perception of common descent, shared culture and ethnic affiliation. Ethnic Chinese businesses organized in 'bamboo-networks' (Weidenbaum and Hughes, 1996), are viewed as the spearheads of Asia's economic growth as well as a major global force. The image of the networking, family-based, flexible and economically successful 'overseas' Chinese business community has become a trope in the literature on transnational relations in contemporary Southeast Asia (cf. Chan, 2000; Coe et al., 2003; Douw, 1999; Gomez and Hsiao, 2001, 2004; Redding, 1990; Suryadinata, 1997; Yeung and Olds, 2000) and beyond (cf. Ong and Nonini, 1997; Ong, 1999). Fuelled by the writings of management gurus like Kotkin (1993) and Naisbitt (1996) ethnic ties - allegedly more committed than other forms of social relations - have been identified as the success formula of 'Asian' businesses. This so-called 'ethnic advantage thesis' has informed much of the writing on ethnic Chinese businesses (Granovetter 2003). Viewed from an institutional perspective, however, ethnicity and culture are social phenomena that can be manipulated by stakeholders in pursuit of their own interests and, consequently, may affect business in a detrimental way. In this vein, institutional scholars have come to analyze ethnic Chinese businesses in terms of their embeddedness (Granovetter, 1985) in multi-layered personal relationships and state patronage (Gomez, 1999, 2002; Gomez and Hsiao, 2004; Jesudason, 1989; Hamilton, 1999; Yeung and Olds, 2000).

While the literature on the ethnic Chinese business community is focusing on those factors that are conducive to business operations in that they reduce risks in complex and insecure environments, little attention has been paid to the manners in which business failure is dealt with (Dahles, 2007a). In this paper, business failure will be investigated in terms of the impact emanating from the embeddedness of ethnic Chinese businesses in complex economic, social-cultural and political configurations. These configurations can be a source of challenges as well as a safety valve against such challenges. In other words, this paper looks into the impacts of the embedded nature of ethnic Chinese businesses on failure management.

A comparative analysis of two different ethnic Chinese communities doing business in China - the Malaysian and the Singaporean -should shed some light on the issue of business failures occurring among its members. Under British rule united in the Malay Union, Malaysia and Singapore split into two separate nation states in 1965 as a consequence of ethnic disturbances between the Chinese and Malay population. Singapore became a city-state with a booming economy and the only place outside of Greater China where the Chinese constitute the majority of the population. Singapore's entrepreneurial government engaged in social and cultural engineering as part of the nation building project designing a hybrid identity for its ethnic Chinese citizens of a distinct Singaporean brand eloquent in both Western and Asian cultural repertoires and mediator between both worlds (Economic Development Board 1995, p. 6). In Malaysia, the ethnic Chinese came to establish a substantial 
minority which constitutes the pillars of the Malaysian economy (Yeung and Olds, 2000), while their citizenship remains contested in the Islamic context of the Malaysian nation state. The Malaysian Chinese are among the least assimilated Chinese groups in Southeast Asia (Ong and Nonini, 1997, p.24-25). While political relations between Malaysia and Singapore were strained after the separation, economic interdependence between both states remained strong (Yeung, 2002).

In the 1980s, when China re-entered the world economy, the Singaporean and the Malaysian Chinese were among the first to take their business to China (Wang and Lin 2008). Presently, Singapore is among the largest foreign investors in China (Bolt, 2000; Kumar et al., 2005), while Malaysian trade with China quadrupled in the 1990s (Bolt, 2000, p.122). However, there is also an increase in business problems and failures of which no records are kept. This paper focuses on business failures among Singaporean and Malaysian ethnic Chinese venturing into China. The analysis will reveal striking similarities and differences in their overall business strategy as much as in their response to business failure. Their shared history on the one hand and the diverging current position in two separate nation states on the other make a comparison of both ethnic Chinese communities worth while, as this comparison will bring to light the significance of embeddedness for the management of business failures.

This paper is structured as follows. Upon elaborating the current theoretical debate on ethnic Chinese transnational business ventures and a description of the database, the paper proceeds with a brief portrayal of the development of Singaporean and Malaysian investments in China since the 1980s. In subsequent sections - featuring a number of exemplary cases presented as vignettes - the empirical findings are first presented and then analyzed. In the concluding section, some reflections on the changing nature of embeddedness of the ethnic Chinese in the two national communities will be advanced.

\section{Embedding Ethnic Chinese Business Failure: Key Concepts}

In terms of Granovetter (1985) one could say that economists exhibit a rather undersocialised approach to business failure designing models for the prediction of financial or corporate collapse with the purpose of future prevention (cf. Altman, 1984). Analyses taking into account the embedded nature of businesses failure are absent from the body of literature. Instead, the writings inspired by the embeddedness approach address human actions detrimental to economic transactions such as disorder, mistrust and malfeasance, actions that are embedded in social relations underlying such transactions (Granovetter, 1985). In much the same vein, it can be argued that the consequence of such upsets business failure - is embedded in social relations as such failure may be generated by business-related mismanagement and lack of entrepreneurial skills as much as irresponsible partners, lack of relevant network connections or restraining government measures.

The significance of the concept of embeddedness for economic transactions has been elaborated by institutional scholars (cf. Zukin and DiMaggio, 1990) arguing that embedded economic activities such as in business communities or business networks are useful institutional means of implementing co- 
operative strategies within and across national borders and enhancing 'institutional thickness' in any business system (Yeung and Olds, 2000, p. 15). In the context of the ethnic Chinese business community, 'institutional thickness' is generated by the embeddedness of businesses in personal relationships (guanxi), high levels of interaction and state patronage (Yeung and Olds, 2000). Ethnic Chinese businesspeople accumulate social capital by maintaining membership in a number of partly overlapping networks (Tracy and Lever-Tracy, 2002; Tan and Yeung, 2000) which comprise of both strong and weak ties (Granovetter, 1973, 1983). In terms of their significance for business success or failure, strong ties may come with weaknesses, while weak ties may show their strength depending on the social context. The strong ties of kinship (with their many-stranded linkages) traditionally play an important role in ethnic Chinese business operations reflecting the economic and political insecurity and the lack of public services available to the ethnic Chinese under diasporic conditions (Cohen, 1997). While Chinese family firms - with the increasing integration of the ethnic Chinese in nation states - may have lost their position of overall capital providers to institutes of formal education providing professional training, credit institutes offering financial support and governments intervening in markets and controlling economic assets, Chinese families still serve as contributor of start-up capital, on the job training of their young, provider of guanxi (Dahles, 2002, 2004, 2005) and support system in times of hardship (Dahles, 2007). Conversely, as has been pointed out by family business scholars, family ties may contribute to business failure because of paternalistic leadership, nepotism, lack of skill and competence (Hsu and Saxenian, 2000; Wijaya 2008) and defensive activities (Carney, 2007). Weak ties - single-stranded relationships with 'acquaintances' (Granovetter, 1983) such as (former) classmates, college friends, co-workers and business relations - have been discussed in terms of their strengths as a significant provider of access to new markets among ethnic Chinese entrepreneurs, in particular in cross-border business ventures (Yeung 2002). However, it has also been show that weak ties may also be weak in trust (Granovetter, 2003) and, therefore, may contribute to business failure. In terms of political embeddedness, the role of the state vis-à-vis private entrepreneurs has to be addressed. In present-day Asia, states are directly involved in economic decisions taken by private entrepreneurs (Beh, 2008; O'Connor and Hutton, 1998). Singapore and Malaysia are described as 'developmental' states since their political leadership advocates marketconforming methods of state intervention (Johnson, 1999; Leftwich, 1995). Under these conditions, government patronage is of great importance for domestic entrepreneurs and the provision or denial of state support to specific (ethnic) groups is greatly affecting business success and failure management.

In order to establish a framework for the analysis of business failures, a number of business strategies will be identified that are characteristic of the Singaporean and Malaysian Chinese venturing into China. These strategies feature partly overlapping categories of actors who may be both supportive and hostile to the business interests of the ethnic Chinese in China. A distinction will be made between two sets of actors: (1) strong ties (family members) and (2) weak ties (acquaintances, peers and professional connections). In addition, (3) the state as the omnipresent actor in the lives of Singaporean and Malaysian businesspeople will be included in the analysis in terms of patronage linkages. 


\section{Methodology}

Underlying this paper are two datasets consisting of case studies of small and medium-sized enterprises (SMEs) in Singapore and in Kuala Lumpur (the capital city of Malaysia). The vast majority of these SMEs are located in the south-eastern part of China, in particular in the Guangdong, Shanghai and Xiamen areas. The Singaporean database includes 32 SMEs with business in China of which 9 discussed with the researcher crises and failures and - in some cases - subsequent re-location of foreign ventures. The Malaysian database consists of 21 SMEs with investments in China of which one failed and left China to relocate business; seven other companies stayed but experienced ongoing business problems which they shared with the researcher. It should be noted that the databases were not established with the purpose of addressing the issue of business failures. This theme emerged spontaneously during the interviews. The numbers offered here are not statistically relevant; they merely describe random occurrence of failure in the database. It is possible that other than the companies discussed here experienced business failure in China at some point but were reluctant to bring this up during the interviews.

The research methods applied in both the Singaporean and Malaysian cases may be characterized in terms of organizational ethnography which is a way of doing fieldwork (Dahles, 2008a). The case studies in the current database have been established during fieldwork in Singapore and Kuala Lumpur extending across an intermittent period of five years. The aim - and at the same time value added - of these ethnographic case studies is the in-depth understanding of the multilayered strategies developed by ethnic Chinese entrepreneurs to establish themselves across national borders. For this purpose, interviews were designed to identify the resources that Chinese entrepreneurs applied during start-up, consolidation and - in a few cases - relocation phases in foreign markets. In Table 1 below an overview is given of all business failures in the combined datasets. The table lists the factors involved in the failure and identifies the strategies of failure management. In addition, a number of companies critical to the understanding of specific actor involvement are presented in vignettes. These cases were selected because they represent striking similarities or sharp contrasts between Singaporean and Malaysian entrepreneurs.

\section{Ethnic Chinese China Ventures}

Chinese firms in Singapore and Malaysia maintain long-standing trade relationships with partners in China that go back to colonial times (Wang and Lin, 2008). The mainland Chinese economic reform and modernization programme since 1979 attracted ethnic Chinese investors who had their ancestral roots there (Tan and Yeung, 2000). In the 1970s Singaporean manufacturing firms set up operations in Guangdong, across the Hong Kong border. The Singaporean government - through their governmentled corporations (GLCs) - started to invest in the same area as early as 1984 (Yeung, 2002, p. 195). While economic exchange between Singapore and China was increasing, official relations between both countries remained distant due the threat emanating from China's support of the communist parties in all countries in the region. 
While Malaysia was among the first Southeast Asian nations to enter into diplomatic relations with China, economic relations did not develop until the 1990s. Partly, this was due to the Communist threat. However, more importantly, the Malaysian government objected to economic relations that would strengthen the economic position of its ethnic Chinese population as this would have undermined the New Economic Policy (NEP) - launched in the 1970s - which aimed at improving the economic position of the Malay population vis-à-vis the ethnic Chinese. Whereas in the 1980s the Malaysian government criticized the ethnic Chinese for trading with China through Singapore agents, in the 1990s, Malaysia made an amazing turnabout encouraging their domestic Chinese entrepreneurs to act as a bridge between the Malaysian economy and China (Bolt, 2000, p. 122).

The 1990s saw increasing numbers of Singaporean and Malaysian Chinese visiting China for purposes of ancestor worship as well as economic investments (Kuah, 1999; Wang and Lin, 2008). Malaysian and Singaporean Chinese entrepreneurs exploited their 'ethnic advantage' - in terms of family ties and language proficiency - strategically when dealing with partners in China. At the same time, their being different - in terms of business skills and technical competences - made them attractive business partners for the mainland Chinese (Chan and Tong, 2000). However, cultural similarities and profitable differences did not guarantee business coalitions to develop successfully (Wang and Lin, 2008).

\section{Encountering Failure: Case Studies}

In this section, empirical evidence of ethnic Chinese business failures in China will be presented based on an embeddedness perspective. The preferential use of family ties and kinship bonds in business ventures is labeled as the 'strong tie' strategy. The utilization of friends and professional relations is labeled as the 'weak tie' strategy. The latter approach has gained of importance with increasing formal education at prestigious schools and overseas universities and employment by multinational companies in early career for obtaining experience and building networks. Conversely, the omnipresence of the developmental state in economic life generated a myriad of new opportunities for local entrepreneurs. Below, for each of the three strategies an exemplary case will be presented in order to illustrate how business failure is related to the strategy applied. This part of the data presentation compares the three different business strategies as such, disregarding national differences. In the next section, the comparison will shift to the similarities and differences between the Singaporean and Malaysian failure cases from the perspective of embeddedness in national communities.

\subsection{Strong Ties}

Trading with China and, in particular, with one's ancestral village, is the 'traditional way' of doing business for many ethnic Chinese firms in Malaysia and Singapore. While successful for many families for many years, the 'Chinese way of doing business' also produced its fair share of bankruptcies. As Case 1 illustrates, the lack of business competence of relatives in China may be part and parcel of failure of such ventures. Other examples in the database confirm that strong ties often turned out weak as because of betrayal, malfeasances or mere incompetence of Chinese kin. 
Case 1

\section{Slippery Smooth Sdn Bhd}

Jimmy Tong, a chemist with a degree from a Taiwanese university, started his factory producing floor cleaners in 1993. He had to start from scratch, as he comes from a family of fishermen who migrated from Guizhou (China) to East Malaysia where they still live. Jimmy's business went well, and soon he obtained a bank loan to buy a bigger factory. With success in the domestic market came the wish to expand across the Malaysian border. Remembering his grandfather's stories of Guizhou, he decided to take his business to China. Looking for partners who knew the country better than he did, he re-established dormant ties with his relatives in Guizhou. His plan was to have his relatives take care of the imports and sales including custom clearance. However, plans went awry. Chinese customs demanded the product to be tested before allowed to enter China. Jimmy refused as he feared that these tests would reveal the secret formula of his floor cleaner and the Chinese would imitate his product. Jimmy requested his relatives in China to intervene. However, they failed to handle this matter adequately for lack of experience and education (they did not know how to proceed) and guanxi (they did not know the right people to push this case). Seeing his first attempt fail, Jimmy decided to set up a subsidiary in Singapore and then develop plans to enter China through a Hong Kong agent. This seemed a safer option to him: "Singapore and Hong Kong is almost the same [as Malaysia]. Because the people there are more rich and their education is higher [than in China]. So, we feel comfortable there. ... The last time it was managed by the British, just like here [in Malaysia]." (Fieldnotes: interview 2004)

\subsection{Weak Ties}

Since the end of World War II, Hong Kong has been a gateway to China and a safe haven for ethnic Chinese people from all over Southeast Asia in times of war, persecution and economic crisis. Huge amounts of money were deposited in or channeled through Hong Kong, affiliate firms were set up and established Southeast Asian conglomerates maintained long-standing interests in Hong Kong (Wang and Lin, 2008). Many Southeast Asians claim kin or lineage ties with residents of Hong Kong, however distant or 'weak' these ties may be. As case 2 illustrates, such ties can easily be renewed for the purpose of business ventures. However, despite the often quoted strength of weak ties (Granovetter 1983), such connections may prove too weak to sustain investments in China.

\section{Case 2}

\section{Templex, a Fashion Trade Company}

Mister Johnson Lee, Singapore born, descends from a Hong Kong business clan. While Singapore based, he sells European fashion products such as cosmetics, perfumes and accessories of famous brand names on both the Singaporean and Malaysian market. His firm did well, but he was also aware of the volatile character of the fashion trade and decided to diversify his business activities. When by chance he came in touch with members of the Hong Kong Lee business clan he was vaguely acquainted with, he jumped at this opportunity. They started a joint venture together and maintained a distant partnership where the Hong Kong people managed the China investments "just across the border" in Guangdong and further away in Shanghai. However, the distant partners made the wrong business decisions by investing Johnson's money in their own company that went bankrupt within three years.

Currently Johnson takes more and more business to Malaysia, where close relatives supported his venture financially. However, his daily affaires operate through two distributors who were introduced to him by reliable customers. Johnson summarizes his lessons from the China failure: "Better to keep things formal where rules are spelt out ... Family businesses rarely work, the company usually collapses when the decision-making process is 
kept in one hand.'

(Fieldnotes: interview 2003)

\subsection{Government patronage}

Another business strategy emerged with the political entrepreneurship of the developmental state and has been most prominent in traditional service sectors such as construction and transportation, distribution and warehousing. In Singapore, in particular, entrepreneurs in these sectors benefited from the large-scale public projects initiated by government agencies like the Port of Singapore Authority, the Mass Rapid Transport Corporation, and the Housing Development Board (HDB). Later - and also emerging in Malaysia with soaring ambitions to establish the Multimedia Super Corridor in Klang Valley - other economic sectors, such as computer technology, benefited from government-initiated projects. Having established patronage linkages with government, entrepreneurs were invited to join government missions abroad, as Case 3 below illustrates.

\section{Case 3}

\section{Green Apple IT Solutions}

Henry Chan, the owner and manager of Green Apple IT Solutions, a Singaporean dotcom firm, is the son of a Singaporean Chinese real estate agent. He obtained an engineering degree from Nanyang Polytechnic in 1990 and an MBA diploma from a university in Australia two years later. Upon his return to Singapore, he held several jobs with foreign MNCs and domestic companies before venturing out on his own. In 1999, Henry was invited to join a government-sponsored trade mission to China which he owed to his father's connections with the HDB engaged in industrial estate development in China. With his name on the list of participants of the HDB mission, foreign and domestic firms with an interest in China investments approached him with investment offers. This led to the establishment of a branch in Shanghai soon encountered problems with local state-owned enterprises. In 2003 Henry considered to pull out of Shanghai, but postponed this decision as another business venture into Beijing was pending. In 2004, while the Green Apple had been taken over by another Singaporean IT firm, its Shanghai branch had split off from the Singaporean parent company and then joined forces with a local IT firm. As his Shanghai business partner was better equipped to deal with the Chinese government and the Chinese market, Henry turned into a silent partner. After four years, Henry's Beijing venture still had not been approved by the Chinese authorities and Henry lost interest in China. Instead, he started a software business in the Malaysian Klang Valley together with old college friends from Australia.

(Fieldnotes August 2000 and May 2004)

Singaporean and Malaysian Chinese firms venture into China in a myriad of ways: in the slipstream of family relations, government-sponsored trade missions, in a joint venture with friends, mediated through an agent or in connection with the relocation of their subsidiary initiated by the company owner. The combined use of strong and weak ties and government patronage reflects the rather adaptive way of doing business among the ethnic Chinese. More often than not, these strategies are pooled to be used selectively constituting a mixed approach. However, while this adaptability has always been viewed as the strength of ethnic Chinese businesses, the cases presented here show that this strength can turn into a weakness that leads to crisis and even bankruptcy. 


\section{Failure Management: a comparative analysis}

There are many similarities in the ways in which Singaporean and Malaysian companies organize their ventures into China and experience and respond to crisis and failures - see table 1. Overall, many of them expected that their alleged strong ties, in particular their family linkages in China, would offer a comparative advantage. Sometimes these strong ties turned out weak: family members lacked the entrepreneurial and social skills and connections to run a subsidiary or solve problems as both Johnson Lee's and Jimmy Tong's story illustrates. In a few cases the Chinese family cheated on their Malaysian or Singaporean kin by using the entrusted funds for other than the agreed purposes. Such betrayal, however, was often blamed on the weakness of these blood-ties, not on the failure of kin as providers of trust. Instead of persuading business people to shift their cross-border strategies from a kin-based to an institutional embedding, the trust in family was re-established by distinguishing between close and distant kin. While kin was identified as distant when located in China and such family-ties were classified as 'weak', relatives living in neighbouring Southeast Asian countries became classified as close kin. Both the family and the countries were qualified in terms of 'strong ties'. The shift then was from defining one's identity as rooted in pre-communist China to locating one's roots in colonial Southeast Asia. As shown in table 1 and illustrated by the three cases, in times of crisis, both Singaporean and Malaysian businesspeople either diversified or relocated business to their closest neighbor: Malaysian entrepreneurs turned to Singapore and Singaporean entrepreneurs to Malaysia. Frequently, the contract law, based on the British legal system that survived de-colonization in many former British colonies, is quoted as an important advantage and, at the same time, binding factor for doing business in countries with a common British colonial past. As Zwart (2006) points out, the establishment of business in countries that possess a functional legislative system of a distinct British origin must be viewed in terms of a risk-reducing strategy. This would explain the preference among Singapore and Malaysian ethnic Chinese for member-countries of the British Commonwealth as locations of their foreign business ventures. It is in these countries that businesspeople can rely on the contract law, the right of redress to the courts and business ethics supporting this system.

Table 1: Overview of China business failures among Singaporean and Malaysian firms

\begin{tabular}{|c|c|c|c|c|c|c|c|}
\hline \multirow{2}{*}{$\begin{array}{l}\text { No. in } \\
\text { sample }\end{array}$} & \multirow[t]{2}{*}{ Location } & \multirow[t]{2}{*}{ Sector } & \multirow{2}{*}{$\begin{array}{l}\text { China } \\
\text { ventures }\end{array}$} & \multirow{2}{*}{$\begin{array}{l}\text { Entry } \\
\text { strategies }\end{array}$} & \multirow{2}{*}{$\begin{array}{l}\text { Reason for } \\
\text { failure }\end{array}$} & \multicolumn{2}{|c|}{ Failure management } \\
\hline & & & & & & In China & Transnationally \\
\hline S04 & Singapore & $\begin{array}{l}\text { Business-to- } \\
\text { business }\end{array}$ & $\begin{array}{l}\text { Failed } \\
\text { start-up }\end{array}$ & $\begin{array}{l}\text { Direct } \\
\text { investment }\end{array}$ & $\begin{array}{l}\text { Lack of strong } \\
\text { and weak ties }\end{array}$ & Pulled out & $\begin{array}{l}\text { Relocation to } \\
\text { Malaysia }\end{array}$ \\
\hline S18 & Singapore & Manufacturing & $\begin{array}{l}\text { Failed } \\
\text { start-up }\end{array}$ & $\begin{array}{l}\text { Direct } \\
\text { Investment }\end{array}$ & $\begin{array}{l}\text { Lack of China } \\
\text { government } \\
\text { patronage }\end{array}$ & Pulled out & $\begin{array}{l}\text { Relocation to } \\
\text { the Middle } \\
\text { East, Australia }\end{array}$ \\
\hline S20 & Singapore & Trade & Failure & Kin & $\begin{array}{l}\text { Cheated by kin } \\
\text { in China }\end{array}$ & Pulled out & $\begin{array}{l}\text { Relocation to } \\
\text { Malaysia }\end{array}$ \\
\hline $\begin{array}{l}\text { S21 } \\
\text { Case } 2\end{array}$ & Singapore & Trade & Failure & $\begin{array}{l}\text { Hong Kong } \\
\text { business } \\
\text { partner }\end{array}$ & $\begin{array}{l}\text { Lack of strong } \\
\text { ties, failure of } \\
\text { weak ties }\end{array}$ & Pulled out & $\begin{array}{l}\text { Relocation to } \\
\text { Malaysia }\end{array}$ \\
\hline S25 & Singapore & Trade & Failure & Distant kin & $\begin{array}{l}\text { Lack of strong } \\
\text { ties, failure of } \\
\text { weak ties }\end{array}$ & Pulled out & $\begin{array}{l}\text { Relocation to } \\
\text { Malaysia }\end{array}$ \\
\hline S47 & Singapore & Manufacturing & Failure & $\begin{array}{l}\text { Direct } \\
\text { investment }\end{array}$ & $\begin{array}{l}\text { Wrong } \\
\text { investment }\end{array}$ & Pulled out & $\begin{array}{l}\text { Relocation to } \\
\text { India }\end{array}$ \\
\hline
\end{tabular}




\begin{tabular}{|c|c|c|c|c|c|c|c|}
\hline $\begin{array}{l}\text { S30 } \\
\text { Case } 3\end{array}$ & Singapore & $\begin{array}{l}\text { Business-to- } \\
\text { business }\end{array}$ & Failure & $\begin{array}{l}\text { Singapore } \\
\text { government } \\
\text { patronage }\end{array}$ & $\begin{array}{l}\text { Lack of China } \\
\text { government } \\
\text { patronage }\end{array}$ & $\begin{array}{l}\text { Silent } \\
\text { partnership } \\
\text { with } \\
\text { Chinese } \\
\text { partner }\end{array}$ & $\begin{array}{l}\text { Diversification } \\
\text { into Malaysia, } \\
\text { US }\end{array}$ \\
\hline S31 & Singapore & $\begin{array}{l}\text { Business-to- } \\
\text { business }\end{array}$ & Failure & $\begin{array}{l}\text { Direct } \\
\text { investment }\end{array}$ & $\begin{array}{l}\text { Lack of strong } \\
\text { and weak ties }\end{array}$ & Pulled out & $\begin{array}{l}\text { Relocation to } \\
\text { Australia, } \\
\text { Malaysia }\end{array}$ \\
\hline S32 & Singapore & $\begin{array}{l}\text { Business-to- } \\
\text { business }\end{array}$ & Failure & $\begin{array}{l}\text { Singapore } \\
\text { government } \\
\text { patronage }\end{array}$ & $\begin{array}{l}\text { Lack of under- } \\
\text { standing China }\end{array}$ & $\begin{array}{l}\text { Joint } \\
\text { venture with } \\
\text { Chinese } \\
\text { partners }\end{array}$ & $\begin{array}{l}\text { Diversification } \\
\text { into UK }\end{array}$ \\
\hline M05 & Malaysia & $\begin{array}{l}\text { Trade } \\
\text { Singaporean } \\
\text { owner }\end{array}$ & Failure & Distant kin & Asian crisis & $\begin{array}{l}\text { Planning a } \\
\text { re-try }\end{array}$ & $\begin{array}{l}\text { Diversification } \\
\text { into Singapore }\end{array}$ \\
\hline $\begin{array}{l}\text { M06 } \\
\text { Case 1 }\end{array}$ & Malaysia & Manufacturing & Start-up & $\begin{array}{l}\text { Distant kin, } \\
\text { Hong Kong } \\
\text { agents }\end{array}$ & $\begin{array}{l}\text { Family } \\
\text { linkages did } \\
\text { not work out }\end{array}$ & $\begin{array}{l}\text { Planning a } \\
\text { re-try }\end{array}$ & $\begin{array}{l}\text { Diversification } \\
\text { into } \\
\text { Singapore, } \\
\text { Hong Kong }\end{array}$ \\
\hline M07 & Malaysia & $\begin{array}{l}\text { Retail } \\
\text { Hong Kong } \\
\text { owner }\end{array}$ & $\begin{array}{l}\text { Ongoing } \\
\text { problems }\end{array}$ & $\begin{array}{l}\text { Hong Kong } \\
\text { linkages } \\
\text { via distant } \\
\text { kin }\end{array}$ & Asian Crisis & $\begin{array}{l}\text { Downsizing, } \\
\text { low profile }\end{array}$ & $\begin{array}{l}\text { Diversification } \\
\text { into Hong } \\
\text { Kong, } \\
\text { Singapore, } \\
\text { Australia, } \\
\text { Indonesia, } \\
\text { Germany }\end{array}$ \\
\hline M16 & Malaysia & $\begin{array}{l}\text { Business-to- } \\
\text { business } \\
\text { Taiwanese } \\
\text { owner }\end{array}$ & $\begin{array}{l}\text { Failed } \\
\text { start-up }\end{array}$ & Kin & $\begin{array}{l}\text { Family } \\
\text { linkages did } \\
\text { not work out }\end{array}$ & $\begin{array}{l}\text { Planning a } \\
\text { re-try }\end{array}$ & $\begin{array}{l}\text { Diversification } \\
\text { into Taiwan, } \\
\text { Singapore, } \\
\text { ASEAN and } \\
\text { India }\end{array}$ \\
\hline M18 & Malaysia & Manufacturing & $\begin{array}{l}\text { Ongoing } \\
\text { problems }\end{array}$ & Distant kin & $\begin{array}{l}\text { Lack of strong } \\
\text { and weak ties, } \\
\text { lack of skills }\end{array}$ & $\begin{array}{l}\text { Downsizing, } \\
\text { low profile }\end{array}$ & $\begin{array}{l}\text { Diversification } \\
\text { into } \\
\text { Singapore, } \\
\text { Hong Kong, } \\
\text { Taiwan }\end{array}$ \\
\hline M19 & Malaysia & $\begin{array}{l}\text { Business-to- } \\
\text { business }\end{array}$ & $\begin{array}{l}\text { Ongoing } \\
\text { problems }\end{array}$ & Distant kin & $\begin{array}{l}\text { Lack of strong } \\
\text { and weak ties, } \\
\text { lack of skills }\end{array}$ & $\begin{array}{l}\text { Downsizing, } \\
\text { low profile }\end{array}$ & $\begin{array}{l}\text { Diversification } \\
\text { into } \\
\text { Singapore, } \\
\text { Hong Kong, } \\
\text { Taiwan, } \\
\text { ASEAN } \\
\end{array}$ \\
\hline M20 & Malaysia & $\begin{array}{l}\text { Trade } \\
\text { Japanese } \\
\text { owner } \\
\end{array}$ & Failure & $\begin{array}{l}\text { Direct } \\
\text { investment }\end{array}$ & $\begin{array}{l}\text { Overall } \\
\text { incompatibility } \\
\text { with China }\end{array}$ & Pulled out & $\begin{array}{l}\text { Relocation to } \\
\text { Singapore } \\
\text { Japan }\end{array}$ \\
\hline M21 & Malaysia & $\begin{array}{l}\text { Business-to- } \\
\text { business }\end{array}$ & $\begin{array}{l}\text { Ongoing } \\
\text { problems }\end{array}$ & Distant kin & $\begin{array}{l}\text { Lack of strong } \\
\text { and weak ties, } \\
\text { lack of skills }\end{array}$ & $\begin{array}{l}\text { Downsizing, } \\
\text { low profile }\end{array}$ & $\begin{array}{l}\text { Diversification } \\
\text { into Singapore }\end{array}$ \\
\hline
\end{tabular}

However, there are also striking differences in the ways in which Singaporeans and Malaysians manage crisis and failure. Comparing their strategies to enter China, the idea of a shared Chinese culture and family linkages as binding factors seems more pronounced among the Malaysian Chinese. All of our Malaysian failure cases entered China through close or distant kin, and many of them also experienced crisis or bankruptcy because of family intervention detrimental to business. 
More Singaporeans than Malaysians ventured into China without the kin-based safety valve or by benefiting from Singapore government patronage (which did not protect them from the consequences of Chinese government intervention as case 3 so aptly illustrates). In Singapore, the government strongly promoted and supported investments in China (Dahles 2007a, 2008b). For Singaporean entrepreneurs, family ties - though not irrelevant - seemed to be less important for the success they hoped to reap from their China venture. Accordingly, the Singaporean companies experiencing failure left China and abstained from further ventures both into China and other foreign countries (cf. Table 1). Few use their experience to direct business ventures into new areas that prove to be more successful. Henry Chan (case 3) may be regarded an exception to the rule. When he down-scaled his involvement in the Shanghai joint venture- without pulling out of China completely - he understood that business opportunities are still huge. But with the global market on his mind, he entered a transnational partnership with former college friends that may be classified as a 'weak ties strategy' located in Malaysia.

The Malaysian entrepreneurs in our sample dealt differently with crisis and failure than their Singaporean counterparts. Only one of the firms experiencing crisis left China permanently and they did so under pressure of their Japanese owner who expected set targets to be reached within a limited span of time according to Japanese rigor. The others stayed on, biding their time and taking losses which they attempted to compensate by diversifying business into other countries. Some, like Jimmy Tong (case 1), pulled out temporarily only to get reestablished in China once they had recovered from their failure. This strategy reflects the greater resilience of Malaysian businesspeople. The divergence in resilience between the Malaysian and Singaporean Chinese may be related to in their differing level of embeddedness in their national communities. Ethnic Chinese businesspeople in Malaysia, in particular in the SME segment, suffered under the restrictions imposed by the NEP and were thrown back onto their family-based resources because of lack of economic capital and patronage linkages with power-holders (Kahn, 1996; Granovetter 2003).

\section{Conclusions}

In contrast to the bright vistas projected by the 'ethnic advantage thesis', many ethnic Chinese learned the hard way that people in China do not share their self-image of tong bao (compatriots), but treat them as foreigners instead (Smart and Smart, 2000, p. 261). Although Singaporeans and Malaysians applied divergent entry strategies into China (Singaporeans relied less on allegedly strong family ties than Malaysians) and replied to failure differently (Malaysians downsized business operations and stayed on, while Singaporeans pulled out completely), they proceed similarly when it comes to developing business strategies based on their China experience. This experience contributed to a reorientation among the ethnic Chinese towards both their national communities and towards each other - and finally has come to affect their transnational business strategies. Singaporeans and Malaysians alike relocate or diversify business in other foreign countries and they do so partially by entering the global market, but most of all by setting up a subsidiary in their neighboring country. This process of re-embedding is intertwined with the diverging identity politics of the Singaporean and Malaysian nation states. For the Singapore cases in this sample, the government-orchestrated self- 
presentation of the Singaporean businessman as a cultural hybrid seemed not to build comparative advantage in China. This experience contributed to a changing attitude towards their closest neighbors, the ethnic Chinese in Malaysia. The relationship between the Singaporean and Malaysian Chinese is ridden with problems that reflect the tense relationship between both nation states defined by ethnic and religious cleavages. However, Malaysia also represents a comfort zone (Zwart 2006) to turn to in times of crisis. Because of the strained but nevertheless close relationship defined by a shared past and a separate but interdependent present, Singaporean and Malaysian ethnic Chinese maintain ties that are both strong and weak enough for joint business ventures.

In Malaysia, the Chinese take pride in their ethnic identity because of their ambivalent position in the Malaysian nation state, which for decades forced them to draw on their ethnic and family-based resources. When business ventures into China became possible and even encouraged, it seemed only natural to strategically employ family connections for business start-ups. However, the reliance on these alleged strong ties declined during the process due to the apparent weakness of such ties. The Malaysian entrepreneurs in this sample came to reconsider adherence to the 'ethnic advantage' thought. The crises and failure they experienced in China taught them that business conditions closer to home were not so bad after all, which improved their identification with their closest neighbors. Both Malaysian and Singaporean Chinese communities reassessed their embeddedness in either a hybrid or an essentialist imagined community and re-embedded themselves in a post-colonial society with a British legal heritage, and hence came to focus their cross-border business activities on each other and other countries with a similar legacy. 


\section{Note:}

1. All personal and company names in this paper are pseudonyms.

\section{Acknowledgements:}

The data collection was implemented under sponsorship of the NWO Aspasia-program titled "Organizational Culture in Transborder Region", which was coordinated by the author in 2000-2005. The author wishes to acknowledge the contribution by Dr. Helen Kopnina who established the Singapore dataset and Dr. Esther Zwart who established the mirroring dataset in Kuala Lumpur. I would like to express my gratitude to the Max Planck Institut für Sozialanthropologie in Halle/Saale (Germany), in particular the project Group ' Legal Pluralism' chaired by Professors Frans and Keebet von Benda Beckmann, for inviting me as a guest to the institute and granting me the time to write this article.

\section{Bibliography:}

Altman, E.I. (1984), “The success of business failure prediction models: An international survey”, Journal of Banking \& Finance, vol. 8, no. 2, pp. 171-198.

Beh Loo See (2008), "Developmental State and Chinese Capitalism: Competition and Collaboration", in E.KokKheng Yeoh and J. Hoi-Lee Loh (Eds.), China in the World. Contemporary Issues and Perspectives. University of Malaya, Kuala Lumpur, pp. 185-209.

Bolt, P. J. (2000), China and Southeast Asia's Ethnic Chinese. State and Diaspora in Contemporary Asia, Praeger, Westport, Conn./London.

Butler, J. E., B. Brown and W. Chamornmarn (2000), "Guanxi and the Dynamics of Overseas Chinese Entrepreneurial Behaviour in Southeast Asia", in J.T. Li, A. S. Tsui and E. Weldon (Eds.), Management and Organizations in the Chinese Context, , Macmillan, Houndmills, Basingstoke and London, pp. 245-268.

Carney, M. (2007), Minority Family Business in Emerging Markets: Organization Forms and Competitive Advantage, Family Business Review, vol. 20, no. 4, pp. 289-300.

Chan Kwok.Bun (2000), "State, Economy and Culture: Reflections on the Chinese Business Networks", in Chan Kwok Bun (Ed.), Chinese Business Networks: State, Economy and Culture”, Prentice Hall and Nordic Institute of Asian Studies, Singapore, pp. 1-13.

Chan Kwok Bun and Tong Chee Kiong (2000), "Singaporean Chinese Doing Business in China", in Chan Kwok Bun (Ed.), Chinese Business Networks: State, Economy and Culture, Prentice Hall and Nordic Institute of Asian Studies, Singapore, pp. 71-85.

Coe, N. M., P. F. Kelly and K. Olds, "Globalization, transnationalism, and the Asia-Pacific”, in J. Peck and H. Wai-chung Yeung (Eds.), Remaking the Global Economy. Economic-Geographical Perspective, Sage, London, pp. 45-60.

Dahles, H. (2002), "Transborder Business: The 'Capital' Input in Singapore Enterprises Venturing into ASEAN and Beyond”, Sojourn Journal of Social Issues in Southeast Asia, vol. 17, no. 2, pp. 249-273.

Dahles, H. (2004), "Venturing across borders. Investment Strategies of Singapore-Chinese Entrepreneurs in Mainland China", Asian Journal of Social Sciences, vol. 32, no. 1, pp. 19-41.

Dahles, H. (2005), "Culture, Capitalism and Political Entrepreneurship: Transnational business ventures of the Singapore-Chinese in China”, Culture and Organization, vol. 11, no. 2, pp. 45-58.

Dahles, H. (2007a), “On (Mis-)Conceptions of Culture as a Vehicle of Business Success. Singapore Chinese Investment Strategies after Failing in China”, East Asia. An International Quarterly, vol. 24, no. 2, pp. 173-193.

Dahles, H. (2007b), "Creating Social Capital as a Competitive Advantage in China. Singapore Chinese Entrepreneurs Venturing into China”, in Business Networks and Strategic Alliances in China. Edited by Stewart Clegg, Yuan Wang and Mike Berrell, Edward Elgar, Cheltenham (UK) and Northhampton (MA, USA), pp. 182- 
Dahles, H. (2008a), “Organizational Ethnography”, in International Encyclopedia of Organization Studies, edited by S.R. Clegg and J.R. Bailey, Sage, London, vol. 3, pp. 1066-1067.

Dahles, H. (2008b) "Institutional Ambivalence and Persistent Legacies. Singapore Chinese Small and MediumSized Enterprises Venturing Across National Borders”, Journal of Developmental Entrepreneurship, vol. 13, no. 4, pp. 485-508.

Douw, L. (1999), "The Chinese Sojourner Discourse”, in L. Douw, C. Huang and M. R. Godley (Eds.), Qiaoxiang Ties: Interdisciplinary Approaches to 'Cultural Capitalism' in South China, Kegan Paul, London and New York, pp. 22-44).

Economic Development Board (1995) Regionalisation 2000: Singapore Unlimited. Singapore: EDB.

Gomez, E.T. (1999) Chinese business in Malaysia: Accumulation, accommodation and ascendance. Curzon Press, Richmond, Surrey.

Gomez, E.T. (2002), "Introduction: political business in East Asia”, in E.T. Gomez (Ed.), PoliticalBusiness in East Asia, Routledge, London and New York, pp. 1-33.

Gomez, E.T. and M. Hsiao (2004), "Introduction: Chinese Business Research in Southeast Asia", in E.T. Gomez and M. Hsiao (Eds.), Chinese Business in Southeast Asia. Contesting cultural explanations, researching entrepreneurship, Routledge, London and New York, pp. 1-37.

Granovetter, M. (1973), “The Strength of Weak Ties”, American Journal of Sociology, vol. 78, no. 6, pp. 13601380.

Granovetter, M. (1983), “The Strength of Weak Ties: A Network Theory Revisited”, Sociological Theory vol. 1, pp. 201-233.

Granovetter, M. (1985), "Economic Action and Social Structure: The Problem of Embeddedness", The American Journal of Sociology vol. 91, no. 3, pp. 481-510.

Granovetter, M. (2003), “The Economic Sociology of Firms and Entreprneurs”, in. R. Swedberg (Ed.), Entrepreneurship. The Social Science View. Ocford University Press, Oxford, pp. 244-275.

Hsu Jinn-Hsu and A. Saxenian (2000), The limits of guanxy capitalism: transnational collaboration between Taiwan and the USA, Environment and Planning A, vol 32, pp. 1991-2005.

Jesudason, J.V. (1989), Ethnicity and the Economy: The States, Chinese Business, and Multinationals in Malaysia, Oxford University Press, Singapore.

Johnson, C. (1999), “The Developmental State: Odyssey of a Concept”, in M. Woo-Cummings (Ed.), The developmental State. Cornell University Press, Ithaca, pp. 32-60.

Kahn, J. S. (1996), "Growth, economic transformation, culture and the middle classes in Malaysia”, in R. Robison and D.S.G. Goodman (Eds.), The New Rich in Asia. Mobile phones, McDonald's and middle-class revolution, Routledge, London, pp. 49-78.

Kuah, Khun Eng (1999), “Anxi Connection: Ancestor Worship as Moral-Cultural Capital”, in L. Douw, C. Huang and M. R. Godley (Eds.), Qiaoxiang Ties: Interdisciplinary Approaches to 'Cultural Capitalism' in South China, Kegan Paul, London and New York, pp. 143-157).

Kotkin, J. (1993), Tribes: How Race, Religion, and Identity Determine Success in the New Global Econom,. Random House, New York.

Kumar, S., S. Siddique and Y. Hedrick-Wong (2005), Mind the Gaps: Singapore Business in China, ISEAS, Singapore. 
Leftwich, A. (1995), "Bringing politics back in: Towards a model of the developmental state", Journal of Developmental Studies, vol. 31, no. 3, pp. 400-427.

Naisbitt, J. (1996), Megatrends Asia: Eight Asian megatrends that are reshaping the world, Simon and Schuster, New York.

O’Connor, K. and T. A. Hutton, "Producer Services in the Asia Pacific region: An Overview of research Issues", Asia Pacific Viewpoint, vol. 39, no. 2, pp. 139-43.

Ong, A. (1999), Flexible Citizenship. The Cultural Logics of Transnationality, Dukes University Press, Durham and London.

Ong, A. and D. M. Nonini (eds) (1997), Ungrounded Empires. The Cultural Politics of Modern Chinese Transnationalism, Routledge, New York and London.

Redding, S. G. (1990), The Spirit of Chinese Capitalism. Walter de Gruyter, Berlin and New York.

Smart, A. and J. Smart (2000), "Failures and Strategies of Hong Kong Firms in China: An Ethnographic Perspective", in H. Wai-chung Yeung and K. Olds (Eds.), Globalization of Chinese Business Firms, Macmillan Press, Houndmills, Basingstoke, pp. 244-271.

Suryadinata, L. (ed.) (1997), Ethnic Chinese as Southeast Asians. ISEAS, Singapore.

Tan Nan Sy (1996), The Political Economy of Singapore's Regionalisation Policy, National University of Singapore.

Tan, Chai-Zhi and H. Wai-chung Yeung (2000), "The Internationalization of Singaporean Firms into China: Entry Modes and Investment Strategies", in H. Wai-chung Yeung and K. Olds (Eds.), Globalization of Chinese Business Firms, Macmillan Press, Houndmills, Basingstoke, pp. 220-243.

Tracy, N. and C. Lever-Tracy (2002), “A new alliance for profit: China's local industries and the Chinese diaspora", in T. Menkhoff and S. Gerke (Eds), Chinese Entrepreneurship and Asian Business Networks, RoutledgeCurzon, London and New York, pp. 65-83.

Wang Wangbo and Lin Zhiqing (2008), "Investment in China: The Role of Southeast Asian Chinese Businessmen", in E. Kok-Kheng Yeoh and J. Hoi-Lee Loh (Eds.), China in the World. Contemporary Issues and Perspectives, University of Malaya, Kuala Lumpur, pp. 147-160.

Weidenbaum, M. and S. Hughes (1996), The Bamboo Network: How Expatriate Chinese Entrepreneurs Are Creating a New Economic Superpower in Asia, The Free Press, New York.

Wijaya, Y. (2008), The Prospect of Familism in the Global Era: A Study on the Recent Development of the Ethnic-Chinese Business, with particular Attention to the Indonesian Context, Journal of Business Ethics, vol. 97, no. 3, pp. 311-317.

Yeung, H. Wai-chung (2002), "Transnational Entrepreneurship and Chinese business networks: the regionalization of Chinese business firms from Singapore”, in T. Menkhoff and S. Gerke (Eds.), Chinese Entrepreneurship and Asian Business Networks, RoutledgeCurzon, London and New York, pp. 184-216.

Yeung, H. Wai-chung and K. Olds (2000), "Globalizing Chinese Business Firms: Where Are They Coming From, Where Are They Heading?”, in H. Wai-chung Yeung and K. Olds (Eds.), Globalization of Chinese Business Firms, Macmillan Press, Houndmills, Basingstoke, pp. 1-30.

Zukin, S. and P. DiMaggio (1990), Structures of Capital: The Social Organization of the Economy, Cambridge University Press, New York.

Zwart, E. (2006), In Pursuit of Comfort. The Transnationalisation Process of Malaysian Chinese Small and Medium Enterprises, VU University Press, Amsterdam. 